\title{
Akurasi Pembacaan GPS pada Android untuk Location Based Service (Studi Kasus: Informasi Lokasi SMA di Palembang)
}

\author{
Reading Accuracy GPS in Android for Location Based Service (case \\ study: Location Information of Senior High School in Palembang)
}

\author{
AHMAD FALI OKLILAS ${ }^{1 *}$, SRI DESY SISWANTI $^{1}$, M DIEKA RACHMAN $^{2}$
}

\begin{abstract}
Abstrak
Telepon pintar sudah menjadi gaya hidup masyarakat saat ini. Selain untuk komunikasi, telepon pintar juga digunakan sebagai alat pencari informasi yang cepat serta bebas, tidak bergantung tempat dan waktu. Pencarian informasi berdasarkan posisi pengguna. Pencarian informasi tempat yang berdasarkan posisi dan waktu dapat dilakukan dengan menggunakan location based service. Permasalahan yang timbul ialah akurasi pembacaan lokasi dari alat yang ada dalam telepon seluler tersebut, yaitu global positioning system (GPS). Pada saat pembacaan, pergeseran titik posisi pengguna dapat terjadi sehingga posisi yang diperoleh tidak berada tepat pada posisi aktual di peta digital. Penelitian ini mengukur akurasi pembacaan dari GPS yang berada dalam perangkat telepon pintar Android. Data diambil berdasarkan studi kasus pada posisi lokasi sekolah SMA Negeri yang ada di Palembang. Pengambilan data dengan membuat aplikasi yang dipasang dalam perangkat telepon pintar yang secara langsung dapat mengambil, mengolah, sampai menampilkan data posisi pada peta digital di telepon pintar pengguna. Setelah data didapat, pengolahan data dengan rumus Haversine dilakukan untuk mengetahui seberapa besar pergeseran lokasi sebagai nilai akurasi alat. Pergeseran lokasi dengan membandingkan hasil pembacaan alat GPS yang berada dalam perangkat Android terhadap GPS komersial (GPS Garmin). Hasil akurasi pergeseran pembacaan yang diperoleh adalah sebesar 10.9489 meter.
\end{abstract}

Kata Kunci: akurasi, Android, global positioning system, location based service

\begin{abstract}
Nowadays, smartphone has become lifestyle. Besides enabling communication, smartphones are also used as a fast information searching tool that independent of place and time. Information searching based on user's location and time can be done using location based services. The problem that arises is the accuracy of global positioning system (GPS). At the time of reading, an error in user's position can occur so that the position is obtained not an actual position on a digital map. This study measured the accuracy of the GPS readings that in the Android smartphone. Data were taken based on case studies of State High School in Palembang. Location data was collected using an application installed in a smartphone device that can directly retrieve, process, and display location data on a digital map in the smartphone. Once the data is obtained, the data was processed using Haversine formula to determine how large the error in the location as the value of the accuracy of the tool. Shifting the location by comparing the readings of GPS devices that are in your Android device to the commercial GPS. The obtained error is 10.9489 meters.
\end{abstract}

Keywords: accuracy, Android, global positioning system, location based service

\section{PENDAHULUAN}

Gaya hidup modern saat ini menjadikan masyarakat tergantung pada teknologi komunikasi. Teknologi yang sangat popular dan pesat perkembangannya adalah telepon pintar atau dikenal dengan istilah smartphone. Telepon pintar sudah menjadi gaya hidup masyarakat saat ini. Selain untuk komunikasi juga digunakan sebagai alat pencari data dan informasi yang

\footnotetext{
${ }^{1}$ Ahmad Fali Oklilas,Jurusan Sistem Komputer Unsri Palembang, 0711581700;

${ }^{2}$ M Dieka Rachman, Program Studi Teknik Komputer Unsri Palembang, 0711379249;

*Penulis Korespondensi: Tel: 081532710539; Surel: faliunsri@gmail.com
} 
cepat serta bebas tidak bergantung pada tempat dan waktu. Pencarian informasi berdasarkan posisi pengguna. Sebagai contoh sebuah kasus seseorang yang dalam perjalanan mengalami kekurangan bahan bakar sehingga dia bertanya-tanya tempat pom bensin terdekat. Berdasarkan posisi dia berada dan pom bensin yang terdekat, dia mencari informasi melalui internet. Pencarian lebih efektif jika pencarian berdasarkan posisi pengguna, jenis pom bensin, dan juga arah jalan menuju tempat tersebut yang diinginkan. Pencarian informasi tempat yang berdasarkan posisi dan waktu dapat dilakukan dengan menggunakan location based service (LBS).

LBS adalah suatu layanan yang menyediakan informasi berdasarkan posisi grafis sebuah perangkat (Amit 2011). LBS terbentuk dari titik perpotongan 3 teknologi, yaitu new information and communication technologies, seperti perangkat bergerak, internet, dan sistem informasi geografis. LBS memiliki 5 komponen utama, yaitu: perangkat mobile, jaringan telekomunikasi, posisi, penyedia layanan, dan penyedia layanan data geografis (Andisum 2009). Dahulu LBS hanya bisa digunakan pada komputer desktop. Seiring dengan perkembangan teknologi mobile, teknologi LBS dapat dipindahkan ke platform mobile yang lambat laun akan menggantikan desktop sepenuhnya (Schwinger 2005). Meskipun teknologi mobile masih memiliki kekurangan seperti pendeknya masa baterai dan terbatasnya memori penyimpanan (Amit 2011; Schwinger 2005). Hal tersebut dapat diatasi dengan mengoptimalkan rancangan perangkat lunak yang digunakan.

Pada penelitian sebelumnya, LBS telah dimanfaatkan sebagai aplikasi pencarian sekolah di Kota Depok seperti yang pernah dilakukan oleh Alamsyah (2013). Alamsyah (2013) mengembangkan aplikasi berbasis Android yang terintegrasi dengan Google Maps yang menyediakan perangkat pengembangan LBS (Amit 2011), berbeda dengan penelitian sebelumnya yang menggunakan peta kostumisasi hasil fotografi pribadi serta jangkauan layanannya yang hanya di sekitar lokasi kampus (Rizqi 2007). Permasalahan yang timbul ialah akurasi pembacaan lokasi dari alat yang ada dalam telepon seluler tersebut, yaitu global positioning system (GPS). Pergeseran titik posisi pengguna pada pembacaan dapat terjadi sehingga posisi aktual di peta digital tidak sama dengan posisi sebenarnya.

Penelitian ini meneliti tentang akurasi pembacaan GPS yang berada dalam perangkat telepon seluler pintar berbasis Android. Untuk itu, sebuah aplikasi yang dipasang dalam perangkat Android dibuat. Aplikasi tersebut secara langsung mengambil data berkali-kali dan langsung mengolah data terbaik. Hasilnya ditampilkan pada perangkat telepon seluler pintar berupa peta digital dengan menambah satu layer pada Google Maps.

\section{METODE}

Penelitian ini mengambil studi kasus pada lokasi sekolah SMA-SMA Negeri di kota Palembang. Selain lokasi peneliti berada di kota Palembang, hal ini juga dikarenakan kota Palembang adalah salah satu kota metropolitan di Indonesia. Penelitian ini dilakukan melalui langkah pengembangan aplikasi Android, pengambilan data di lokasi, perbandingan hasil data GPS Android dan GPS Garmin, serta pengolahan dan analisis data.

Langkah pertama adalah membuat aplikasi Android yang dipasang pada telepon pintar. Setelah itu, pengambilan data di lapangan dilakukan pada 15 lokasi sekolah yang ada di kota Palembang. Pada setiap titik lokasi dilakukan 5 kali pengukuran. Data yang diambil menggunakan dua perangkat, yaitu telepon seluler pintar yang dilengkapi perangkat GPS dan GPS komersil standar, yaitu GPS Garmin. Perangkat berbasis Android yang digunakan ialah Samsung Galaxy Tab 2 7", sedangkan GPS Garmin yang digunakan ialah tipe GPSMAP 76CSx. Data dari GPS Garmin yang berbentuk degree minute second (DMS) diubah ke bentuk desimal menggunakan persamaan 1 agar keduanya dapat dibandingkan. Konversi format koordinat dilakukan karena GPS Garmin membaca koordinat dalam format DMS, sedangkan koordinat yang didapat dari pembacaan GPS Android memiliki format desimal.

$$
\text { Desimal }=(\text { Degree })+(\text { Minute } / 60)+(\text { Second } / 3600)
$$


Pada tahap berikutnya, data diolah. Sebagai contoh dari satu lokasi ada 5 pengukuran dicari harga rata-ratanya. Dari pengukuran yang dilakukan di lapangan dengan sampel 15 sekolah SMA Negeri di kota Palembang. GPS mengukur garis lintang dan garis bujur setiap lokasi sebanyak 5 kali kemudian dicari harga rata-ratanya. Hal ini dilakukan dengan dua peralatan, yaitu GPS yang ada pada telepon seluler pintar dan GPS Garmin dengan masingmasing 5 kali pengambilan di tiap lokasi yang sama. Setelah itu, kesalahan pengukuran (galat) dari alat GPS berbasis Android terhadap GPS Garmin diukur menggunakan persamaan 2.

$$
\text { Error Koordinat GPS }=\left(\left[\mathrm{X}_{\text {asli }}-\mathrm{X}_{\mathrm{GPS}}\right] \mathrm{x} 100\right) / \mathrm{X}_{\mathrm{asli}}=\%
$$

Keterangan:

$\mathrm{X}_{\text {asli }} \quad$ : nilai koordinat asli

$\mathrm{X}_{\mathrm{GPS}} \quad$ : nilai koodinat GPS

Selanjutnya, data diolah dan kebaikan akurasi pembacaan dari sistem LBS yang menggunakan GPS pada perangkat telepon seluler pintar berbasis Android dianalisis. Analisis dilakukan dengan membandingkan hasil pembacaan dari peralatan GPS yang sudah standar menggunakan persamaan 3. Persamaan 3 ini juga menjadi penentu akurasi hasil pembacaan lokasi dari perangkat Android.

$$
d=2 r \sin ^{-1}\left(\sqrt{\sin ^{2}\left(\frac{\emptyset_{2}-\emptyset_{1}}{2}\right)+\cos \left(\emptyset_{1}\right) \cos \left(\emptyset_{2}\right) \sin ^{2}\left(\frac{\varphi_{2}-\varphi_{1}}{2}\right)}\right)
$$

Keterangan:

$d$ : Jarak antara dua titik.

$\emptyset_{1}:$ Garis lintang titik pertama.

$\varphi_{1}$ : Garis bujur titik pertama.

$r \quad$ : Konstanta radius bumi $(6378,14 \mathrm{~km})$

$\emptyset_{2}$ : Garis lintang titik kedua.

$\varphi_{2}:$ Garis bujur titik kedua

Kalibrasi perangkat GPS Garmin diawali dengan mencari sinyal satelit. Setelah ditemukan satelit pada layar akan muncul beberapa lokasi satelit dan mendapatkan posisi satelit yang paling kuat sinyalnya. Jika kita sudah mendapatkan sinyal satelit maka kita dapat melakukan pengukuran menggunakan GPS. Minimal satu satelit yang memberi sinyal tetapi pada siang hari dapat lebih dari satu, bisa dua atau tiga bahkan lebih. Sinyal satelit yang paling kuatlah yang akan memberikan informasi ke alat GPS.

\section{HASIL DAN PEMBAHASAN}

Antarmuka aplikasi yang dibuat disajikan pada Gambar 1 dan Gambar 2. Gambar 1 merupakan tampilan aplikasi hasil dari layar telepon seluler pintar pada saat pengambilan data di lapangan. Gambar 2 memperlihatkan lokasi sekolah dan titik yang menunjukkan lokasi pengguna saat itu serta rute menuju lokasi pada peta digital. Informasi tersebut juga diperkaya dengan informasi tambahan lainnya yang berada di bawah peta.

Hasil akhir pengukuran setelah dilakukan tahap-tahap pengolahan data dari 15 sekolah sebagai sampel ditampilkan sebagai hasil akhir pada Tabel 1. Nilai pergeseran tertinggi sekitar 22.9 meter dan terendah sekitar 3.15 meter. Pergeseran titik dari pembacaan GPS pada Android dibandingkan dengan GPS Garmin rata-rata sebesar $0.010949 \mathrm{~km}$ atau 10.949 meter. Dari hasil ini dapat diketahui bahwa pembacaan GPS berbasis Android mengalami pergeseran dari titik sebenarnya rata-rata sebesar 10.949 meter. Artinya, tingkat akurasi pembacaannya relatif jauh sehingga, jika kita berada di suatu lokasi, kita harus menganggap diri kita berada sekitar kurang lebih 11 meter dari lokasi tersebut. Hal ini perlu menjadi perhatian bahwa jika di depan kita ada jalan berbelok, jangan segera berbelok sebab bisa saja masih 11 meter lagi baru kita harus berbelok. Hal ini juga menunjukkan bahwa keterbatasan kemampuan GPS berbasis Android karena memang bukan dirancang sebagai alat ukur utama GPS tetapi sebagai aksesoris pelengkap yang dipasang pada peralatan telepon pintar. Akan beda halnya jika memang menggunakan GPS komersil yang hanya dibuat untuk satu fungsi yaitu sebagai GPS. Standar ketelitian posisi yang diberikan oleh survei GPS berdasarkan SNI 19-6724-2002 untuk posisi absolut 8 meter sampai 10 meter. 

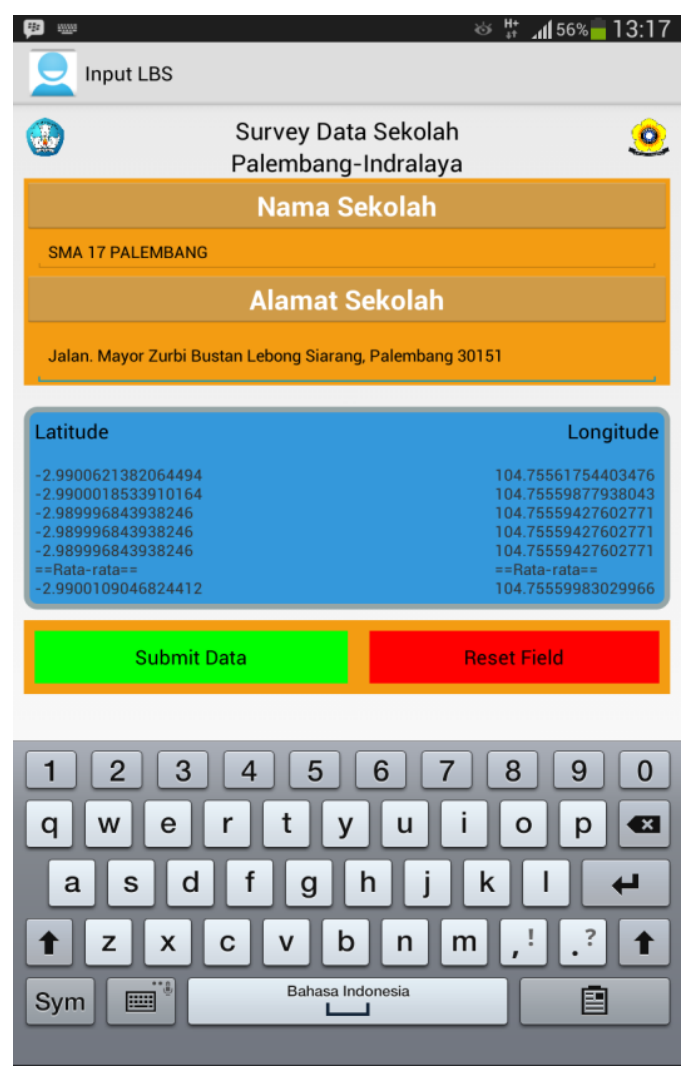

Gambar 1 Antarmuka aplikasi pada Smartphone Android untuk pengukuran lokasi

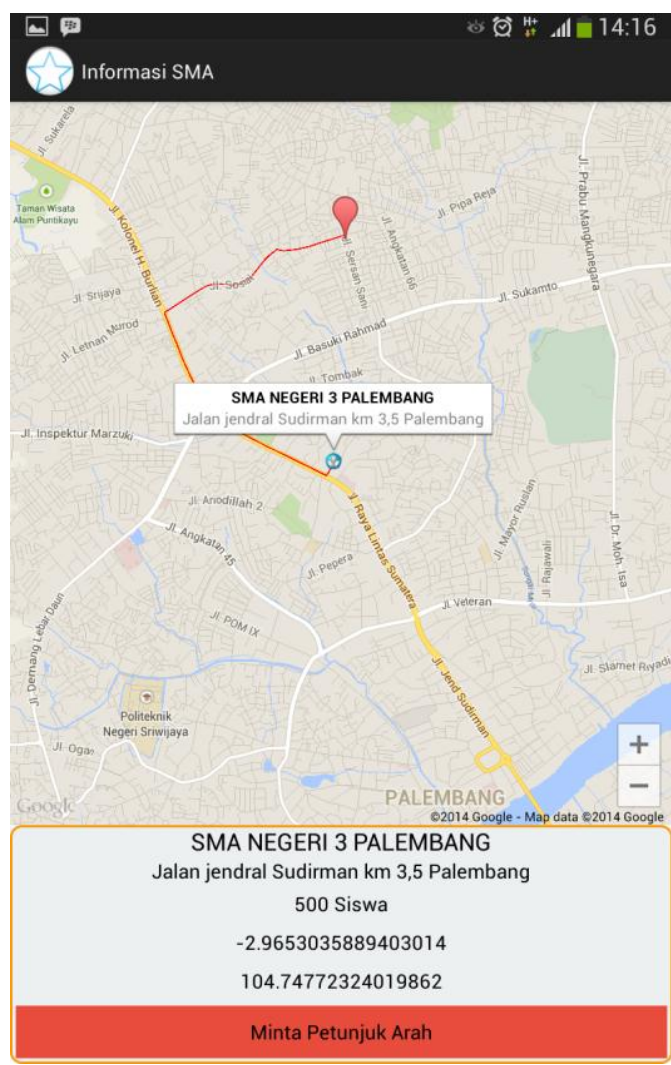

Gambar 2 Antarmuka aplikasi LBS pada Smartphone Android dan peta digital

Tabel 1 Pergeseran titik hasil pengukuran lokasi sekolah SMA Negeri di Kota Palembang

\begin{tabular}{lcr}
\hline \multirow{2}{*}{ Sekolah } & \multicolumn{2}{c}{ Pergeseran } \\
\cline { 2 - 3 } & $\mathrm{Km}$ & \multicolumn{1}{c}{ Meter } \\
\hline SMA Negeri 1 & 0.007494 & 7.494353 \\
SMA Negeri 2 & 0.003507 & 3.506883 \\
SMA Negeri 3 & 0.015019 & 15.018750 \\
SMA Negeri 5 & 0.008454 & 8.454428 \\
SMA Negeri 6 & 0.013563 & 13.563240 \\
SMA Negeri 8 & 0.010004 & 10.004321 \\
SMA Negeri 9 & 0.022903 & 22.903495 \\
SMA Negeri 10 & 0.003154 & 3.154474 \\
SMA Negeri 11 & 0.011309 & 11.309075 \\
SMA Negeri 13 & 0.010458 & 10.458415 \\
SMA Negeri 14 & 0.015431 & 15.430597 \\
SMA Negeri 17 & 0.004429 & 4.429306 \\
SMA Negeri 19 & 0.016704 & 16.704367 \\
SMA Negeri 20 & 0.018246 & 18.245827 \\
SMA Negeri SUMSEL & 0.003556 & 3.556479 \\
\hline \multicolumn{1}{c}{ Rata-rata } & 0.010949 & 10.948934 \\
\hline
\end{tabular}

\section{SIMPULAN}

Simpulan dari penilitian ini ialah GPS Android pada telepon seluler pintar memiliki pergeseran titik pembacaan dari posisi sebenarnya rata-rata sebesar 10.949 meter, masih di atas standar akurasi posisi absolut. Pembuatan aplikasi LBS dapat diterapkan pada telepon seluler 
pintar berbasis android yang memiliki kelengkapan GPS. Peta digital juga dapat ditambahkan dengan menambahkan lapisan (layer) pada Google Maps. Untuk pengembangan, selanjutnya dapat dibuat aplikasi LBS dan yang dapat dengan cepat mengoreksi akurasi pembacaan GPS Android juga dapat ditambahkan informasi lain pada peta digital sesuai kebutuhan pengguna seperti potensi sumber daya alam suatu daerah.

\section{UCAPAN TERIMA KASIH}

Kami mengucapkan terima kasih kepada Fakultas Ilmu Komputer Universitas Sriwijaya yang telah memberikan dana penelitian pada tahun 2014 ini. Terima kasih juga kepada para pembahas tingkat Fakultas Ilmu Komputer Universitas Sriwijaya yang telah memberikan masukan pada tahap laporan kemajuan dari penelitian ini sehingga kami bisa melanjutkan menjadi paper untuk dikirim pada seminar nasional ini.

\section{DAFTAR PUSTAKA}

Amit Kushwaha, Vineet Kushwaha. 2011. Location Based Services using Android Mobile Operating System. International Journal of Advances in Engineering \& Technology. Vol. 1,Issue 1,(March 2011): 14-20.

Andisun. 2009. Global Positioning System. [diunduh 2012 Des 12]. http://www.andisun.com/wpcontent/uploads/2009/07/satelitte_24_gps.png

Ch. Radhika Rani, A. Praveen Kumar, D. Adarsh, K. Krishna Mohan, K.V.Kiran. 2012. Location Based Services In Android. International Journal of Advances in Engineering \& Technology. (March 2012): Springer.

E-tutorial. 2008. Overview of GPRS Network. [diunduh 2013 Sep 20]. http://etutorials.org/Mobile+devices/gprs+mobile+internet/Chapter+3+Overview+of+GPRS/

E-tutorial. 2008. Overview of GPRS Network. [diunduh 2013 Sep 20]. http://etutorials.org/Mobile+devices/gprs+mobile+internet/Chapter+2+GPRS+Services/ClientServer+Relation/

Lee Sunguk. 2012. Creating and Using Databases for Android Applications. International Journal of Database Theory and Application Vol. 5, No. 2, June 2012.

Machliza Rizqi. 2007. Percobaan Aplikasi Picture Location Based Service (LBS) Studi Kasus di Kampus Unjani [skripsi]. Cimahi (ID): Universitas Jendral Ahmad Yani.

Muhammad Vallery Alamsyah. 2013. Pembuatan Aplikasi LBS Untuk Mencari Sekolah Negeri di Depok Berbasis Android [skripsi]. Depok (ID): Universitas Gunadarma.

Nercraft. 2013. Web Server Survey. [diunduh 2013 Sep 12]. http://news.netcraft.com/archives/2013/06/06/june-2013-web-server-survey-3.html

Nixon Robin. 2012. PHP MySQL JavaScript And CSS 2nd Edition. United States of America : O'Reily Media, Inc.

R.Chopde Nitin,Nichat Mangesh. Landmark Based Shortest Path Detection by Using A* and Haversine Formula. International Journal of Innovative Research in Computer and Communication Engineering. Vol. 1, Issue 2, April 2013.

T D'Roza, G Bilchev. 2003. An overview of location-based services. BT Technology Journal 21(1): 2027.

W. Schwinger, C Grin, B Prll1, and W Retschitzegger. 2005. A light-weight framework for locationbased services. In Lecture Notes in Computer Science. Berlin. Springer: 206-210.

----. 2002. Standar Nasional Indonesia (SNI 19-6724-2002) Jaringan Kontrol Horizontal. Badan Standardisasi Nasional. 